\title{
A View To Philosophy On The Process Of Artistic Creation
}

\author{
Prof. Dr.Ömür BÜTEV DOLĞUN \\ (Department of Fine Arts Education, Artvin Coruh University, Turkey)
}

\begin{abstract}
The phenomenon of art has always been one of the primary subjects that philosophers preoccupied, ever since the early ages. Along with how and under which circumstances the process of creation is being occurred and the reason of people's need for it; it is also the reason of people's sympathy and the meanings that people assigned to it that always catches the attention of people. This phenomenon has also drawn the attention of many philosophers since Plato and the philosophers had also expressed different opinions on this topic. While Plato approaches the art as "the reflection of the idea"; Aristoteles states that the art "reflects or should reflect what is supposed to be". When humankind's general development and sociology is considered; this curiosity and the need of analysing the art is still continues. In this study; the philosophical content and interpretations in the art of music are being revealed with examples from the history and the philosophical meaning that various musical pieces from different periods of time contains are trying to be solved and explained in the light of these examples.
\end{abstract}

Keywords:- Music, philosophy, philosophy of music, philosophy of art, work of art

\subsection{The Concept of Philosophy of Art}

\section{INTRODUCTION}

Being one of the first philosophers, Plato says that all objects have an idea before they come into existence and everything shapes according to this idea. According to Plato who states every object in the nature is an imitation of this idea, art is also an "imitation of an imitation" because it actually imitates these objects. According to his thought, all objects and creatures are actually the reflections of these ideas just as the shadows are the reflections of an object. When it is considered that way; Suut Kemal Yetkin comments the philosopher's thoughts on art and artists in his book "Aesthetic Doctrines" as "The purpose of the artist is seeing the beauty in the world, raising them to the ideas and reflecting them in his artworks." (Yetkin, 1972; 17). İhsan Turgut (1993) also agrees with Yetkin on this commentary and says Plato is maybe the first ever philosopher to views art as a reflection, emulation or imitation. According to all these, an artist who had made a painting or sculpture of an object in the nature had actually made the imitation of the nature. This situation also reflected especially on pre-Renaissance and post-Renaissance periods. In most artworks that have managed to make it from that period to our day; the artworks had been counted as beautiful and successful as the motifs that represents the inspired people, object or animal looked more like the original ones. It can actually be said this thought is still valid for some even in our age. By contrast with that, Aristo was talking about the thought that art does not only reflects what actually exists than what should exist even though it is a certain imitation in his work Poetika as he says "And so tragedy is the imitation of a motion that is ethically staid, has a definite beginning, end and length and has a language that is artistically beautified." (Aristo, 1963;22) At this point, it should be thought that the comments of a period define the general opinion and liking of that period. There actually is an idealism, an idealisation in this expression. For Aristo, an artist should be a person who defends or should defend not what is in front of him but the things that are in the world of ideals which means the ones in his dreams. This opinion which can be accepted as the basis of Romantic Movement in $19^{\text {th }}$ century, as it is mentioned before, has undoubtedly contains an idealism.

\subsection{The thoughts of Hegel and Marx}

It is both a historical and psychological truth that the thought of an artist who has been inspired by the Romantic Movement, in other words who had lived during that period has actually comes from idealism. Romanticism and idealism are almost twin siblings. Another view that agrees with this opinion belongs to Hegel. Hegel had also shown a romantic approach to this matter and interpreted art as a reflection of the soul. Unlike many thinkers that come after him; he stated that art cannot be interpreted through intelligence but only through Geist. According to Bozkurt (2013); Hegel who attached importance to intuitions and sensations in contrast to Kant's rationalistic approach viewed the art of music as "the highest expression of inner light and a device of a spontaneous flow, an uninterruption". Hegel also states that the purpose of an artist is not to imitate 
the nature directly but to reflect what is ideal and that the beauty in art is more exalted than the beauty in nature: "... Such that the natural beauty is a basic illusion, fallacy, misgiving and a önduygu that is doomed to fade away. Beauty gains its genuine reality in art." (Bozkurt, 2009;157) This opinion, although it seemed to almost affect Marx' statements about art, then turned into a form that emphasizes art is necessary and beneficial for the society and that it should be used appropriately to the society's needs and purposes. Even in this discourse there actually is an idealism. Reflecting the idealised nature through art becomes the foundation of Hegel's thoughts on art. In that point, it can be said that Hegel agreed on Aristo's thoughts and opinions. Aristo claims on his work Poetika that "The duty of the poet is to express not the one that is really there but what may be there, in other words the thing that is possible according to probability and obligation laws. (Aristo, 1963;30)

\subsection{The effects of Philosophy on the art of music}

That is also a fact that realism and idealism are not so apart from each other nor each other's contrasts in artistic fields. The truth is an artist indeed gets affected by external stimulations certain objects or events that while creating his artwork but he eventually represents the emotions that are recalled or better said idealised by these stimulations on his artwork. That is to say there actually is an idealism in every artwork but its dimensions are different in each artwork. Eventually, it is a known fact that everything exists with its contrast. In which means the two of them are an indivisible whole. Pythagoras and Heraclites also thought in this way and defined the superior law as the attuning of contrast powers to each other.* This phenomenon also affected Schelling and Hegel in $18^{\text {th }}$ century. For them, what maintains the perfect unison of nature is the concord of contrast powers. ** In our day, the thought of the existence of each matter with its contrast is a thought that is not being negated by anyone. Its examples are rather often in the art of music as well. For instance: Inconsonant notes called dissonance are being dissolved into consonant notes a meter or a beat later. This incident usually occurs through chords. Especially when it comes to the works of Baroque period which are hectically polyphonic and based upon counterpoint, the development of harmonic structures has remarkably accelerated. It can easily be observed when the works of that period are examined. As a result of that a chord or note where all the tension is disentangled had always been put in after the dissonant chords or notes that include tension and there occurred a higher chance at encountering a harmonic structure made of contrasts. By that, it is provided for contrast to balance each other and actualise a distinctive harmony.It can be interpreted when it's being viewed from a perspective of music philosophy that in $19^{\text {th }}$ and especially $20^{\text {th }}$ century new seekings and tendencies started to occur. It is observed when the composings up until that period are examined that the general opinion in music was to create a dulcet work made of consonant notes and tonalities, which is rhythmically tense and odd meters or syncopes are not frequent. Every one of the artworks that were made up until these periods are appropriate to value judgements and likings of the society and they are the types that can easily be accepted by the society. Nevertheless especially in the period of the beginning of the end of monarchy and the distinction between the common people and aristocrats, socialistic remarks started being more and more notable. In this period when the majority of population are living under the pressures of a distinctive social class and class discriminations peak; it should be seen as a foregone conclusion that there occurred some events that were led by intelligentsias and artist and that these events had brought some new approaches along. This situation, is a social explosion.

\section{CONCLUSION}

The generally observed displeasure had also reflected on the art of music as well as on other field of arts. It can be said that especially the wars and various deficiencies that came after had made people ever increasingly conscious. This situation that was also reflected in art can be summarized as: "Conflict within a work of art comes from its relation to practical lived experience" (Jessop, 2016:7) Music is also important on emphasizing a thought or emotion that is tried to be told. In this respect, when it comes to music's accompaniment with language "When music accompanies words, its significance customarily lies in underlining or counterpointing the meaning of the text." (Sharpe, 2015; 85)Thus it can be said that until Arnold Schoenberg's, one of the most remarkable composers of $20^{\text {th }}$ century, period there were works in almost every styles, forms and in tonalities were being composed and being vocalised and that it is a must to find a new approach and to verge to new seekings for the sake of the art of music. In this context, some may think that the methods that are found by Shoenberg are a natural approach by these seekings, it can still be interpreted that these new methods are getting closer to the concept of socialist realism.It can't be thought that the upheavals that include the wars of that period and economic, social, political, social problems and predicaments that came along do not have any affects on the artist of that period. Thus methods like dissonant notes, atonality, various syncopes that Schoenberg used on his works are the social, economic, political and social problems that reflected on his artworks. According to this argument, art does not reflect what is there or the imitation of it, contrarily, it reveals the reality that is there with all its explicitness. It can be said that this understanding is there even in an abstract art like music. In short, the truth that Schoenberg and many other composers who lived in that period had showed us is actually "the truth that the emperor has no clothes". 


\section{NOTES}

* This situation was also touch on by Pierre Ducasse in his book "Büyük Felsefeler". In the relevant chapter of the book (page 24) it is also being mentioned that the harmony does not obtain a numerical relation. Though a mathematical relation is not being mentioned, the musical mathematical correlation that is used in distinguished works of Baroque and Classical Period can be considered. The musical structure that is shaped by exclusive harmonical rules is based on a system that can be considered as mathematical. What is distinctive is the dulcet notes come from this system.**This situation which is based on the fact that everything exists with its contrast was pointed out on the $130^{\text {th }}$ page of the same book. The fact that contrast harmonic structures enrich the value of musical artworks is a fact that can be easily observed.

\section{REFERENCES}

\section{Books:}

[1] S.K.Yetkin,Estetik Doktrinler,(Bilgi Yayınevi,Ankara:1972)

[2] İ.Turgut, Sanat Felsefesi,(Üniversite Kitabevi, İzmir: 1993)

[3] Aristoteles, Poetika, (Remzi Kitabevi, İstanbul:1963)Sayfa:22(1450 a)

[4] N.Bozkurt, Hegel, (Fikir Mimarları I, Say Yayınları, İstanbul:2009)

[5] N.Bozkurt,Sanat ve Estetik Kuramları(Sentez Yayıncılık, Sentez Felsefe Kitapları:22,10.Basım, Ankara:2013)

[6] P.Ducasse, Büyük Felsefeler,(Varlık Yayınları,Faydalı Kitaplar:121,Sayı:1679, İstanbul:1972)

[7] R.A.Sharpe, Philosophy of Music:An Introduction,(Routledge, Taylor and Francis Group,New York: 2014)

[8] A.Bowie, Music, Philosophy, and Modernity (Series:Modern European Philosophy, Cambridge University Press, New York: 2007)

\section{Journals Papers:} [1] S. Jessop,(2016): Adorno: Cultural Education and Resistance, Studies in Philosophy and Education, Open Access,p.1-15
http://link.springer.com/article/10.1007/s11217-016-9531-6 